\title{
Deoxyribonucleic Acid Homology and Base Composition in Some Thermophilic Lactobacilli
}

\author{
By F. DELLAGLIO, V. BOTTAZZI \\ Istituto di Microbiologia lattiero-casearia, Università \\ Cattolica del Sacro Cuore, Piacenza, Italy \\ AND L. D. TROVATELLI \\ Istituto di Microbiologia Agraria e Tecnica, Università \\ degli Studi, Bologna, Italy \\ (Received I3 December 197I; revised 4 September 1972) \\ SUMMARY
}

Thirty-two culture collection strains of the thermophilic species of the genus Lactobacillus (Lactobacillus helveticus, L. jugurti, L. bulgaricus and L. lactis) and I 3 field strains from natural whey cheese cultures were examined by routine physiological and serological tests. Genetic relatedness was determined by DNA-DNA molecular hybridization.

General agreement was observed between the phenotypic traits and genome homology. The close phenotypic resemblance between Lactobacillus helveticus and $L$. jugurti and between $L$. bulgaricus and $L$. lactis was confirmed by the genetic findings.

\section{INTRODUCTION}

On the basis of morphological, physiological and biochemical characteristics, OrlaJensen (I9I9) divided the genus Lactobacillus into three groups: Thermobacterium, Betabacterium and Streptobacterium. These groups were further subdivided into several species that are currently accepted (Breed, Murray \& Smith, 1957; Rogosa \& Sharpe, 1959; Sharpe, I96I ; Hansen, I968). However, it is sometimes difficult to distinguish between lactobacilli on the basis of phenotypic characters, particularly field strains from a large diversity of habitats.

DNA-DNA hybridization may prove a useful method in classification and may reveal taxonomic differences which might otherwise be obscured by similar phenotypic characteristics. The genus Bifidobacterium, for example, was shown to contain several unrelated groups by DNA-DNA hybridization even though the strains resembled each other in metabolic pathways, fermentation patterns, morphology and other characteristics (Scardovi et al. 1971).

Recent studies by Miller, Sandine \& Elliker (197I) and by Simonds, Hansen \& Lakshmanan (197I) on the lactic acid bacteria showed that the extent of DNA hybridization, which reflects in part the similarity of the base sequences of the bacterial genome, is a useful technique in taxonomic studies of this group.

The present investigation deals with the extent of molecular hybridization between some thermophilic species of the genus Lactobacillus and some freshly isolated lactobacilli. 


\section{METHODS}

Organisms. The strains used are given in Table $\mathrm{I}$. The identity of the cultures was checked by the bacteriological tests recommended by Rogosa \& Sharpe (1959).

The preparation of antigens, of antisera and their absorption and technique of precipitin tests were carried out by the methods of Sharpe (I955).

Table I. List of strains

\begin{tabular}{|c|c|c|c|}
\hline Organism & Strain* & Organism & Strain * \\
\hline Lactobacillus lactis & ATCC I I 06I & L. jugurti & ATCC 52 I \\
\hline L. lactis & NIRD AHI 6 & L. jugurti & NIRD WLI9 \\
\hline L. lactis & NIRD L27 & L. jugurti & NIRDJI9 \\
\hline L. lactis (NCDO270, ATCC 8000) & NIRD LI & L. jugurti (NCDOIOI, & \\
\hline L. lactis (NCDO 297, ATCC 10697) & NIRD L2O & ATCC 7994) & NIRDJIO \\
\hline L. lactis $(\mathrm{NCDO} 280)$ & NIRD L3 & L. jugurti $(\mathrm{NCDO} 48 \mathrm{I})$ & NIRD JI4 \\
\hline L. lactis & NIRD AH4O & L. jugurti & IMBOS29.9 \\
\hline L. lactis & NIRD LI 2 & L. jugurti & IMBOS40.8 \\
\hline L. bulgaricus & NIZO 3503 & L. jugurti & IMBOS20.7 \\
\hline L. bulgaricus & NIRD BI 5 & L. jugurti & IMBOSI 3.8 \\
\hline L. bulgaricus & NIRD BI & L. jugurti & IMBOS3.I \\
\hline L. bulgaricus & NIRD BI 7 & Unnamed lactobacilli $\uparrow$ & IMPCL $5 b$ \\
\hline L. bulgaricus & ATCC I 1842 & & IMPCMIC \\
\hline L. bulgaricus & ATCC 12278 & & IMPCM5C \\
\hline L. helveticus & NIRD HI & & IMPCMt 57 \\
\hline L. helveticus & NIRD HI 8 & & IMPCMCOI7 \\
\hline L. helveticus (АTCC I0386) & NIRD H4 & & IMPCMAI \\
\hline L. helveticus & NIRDPR3 & & IMPCZI 8 \\
\hline L. helveticus & NIRDH5 & & IMPCM32 \\
\hline L. helveticus & NIRD WL7 & & IMPC Lde \\
\hline L. helveticus & NIZO 3527 & & IMPCMV8 \\
\hline \multirow[t]{3}{*}{ L. helveticus } & ATCC 10797 & & IMPCMg2 \\
\hline & & & IMPCMrI \\
\hline & & & IMPC LM4 \\
\hline
\end{tabular}

* ATCC, American Type Culture Collection, Rockville, Maryland; NIRD, M. E. Sharpe, National Institute for Research in Dairying, Reading, England; NIzo, Nederlans Instituut voor Zuivelonderzoek, Ede, Holland; IMBO, Istituto di Microbiologia, Università di Bologna, Italy; IMPC, Istituto di Microbiologia, Università Cattolica del Sacro Cuore, Piacenza, Italy.

$\dagger$ Recently isolated from natural whey cheese cultures.

Preparation of antisera. Lactobacillus helveticus NIRDH I and L. jugurti ATCC 52I were used to prepare group A antisera and L. bulgaricus NIRDBI and $L$. lactis NIRDLI were used to prepare group E antisera. The organisms were grown in $10 \mathrm{ml}$ of MRS (De Man, Rogosa \& Sharpe, 1960) medium at $37^{\circ} \mathrm{C}$ for $\mathrm{I} 8 \mathrm{~h}$; the bacteria were collected by centrifuging, washed twice in $0.85 \%$ saline and suspended in $10 \mathrm{ml}$ saline. Suspensions were heated at $60{ }^{\circ} \mathrm{C}$ for I $\mathrm{h}$, diluted and used for a course of seven intravenous inoculations at 4-day intervals in rabbits. The antisera were tested for potency and specificity and then stored at $4{ }^{\circ} \mathrm{C}$ with $0.01 \%$ merthiolate.

Absorption of antisera. When antisera cross-reacted with extracts of strains from other groups the antisera were absorbed with the heterologous strains using I vol. of packed fresh cells and 4 vol. of serum. As noted by Sharpe (I955), absorption weakened the potency of antisera so that unabsorbed antisera were used whenever possible.

Preparation of antigens. Bacteria, grown in $40 \mathrm{ml}$ of MRS in which Yeastrel was replaced by tomato juice $(\mathrm{I} \%, \mathrm{w} / \mathrm{v})$, were collected by centrifuging and extracted with $2 \cdot 0 \mathrm{ml}$ of $0.05 \mathrm{~N}-\mathrm{HCl}$ in saline in a boiling water-bath for $\mathrm{I} 0 \mathrm{~min}$. Extracts were neutralized, centrifuged and stored at $4{ }^{\circ} \mathrm{C}$ with $0.01 \%$ merthiolate. 
Precipitin test. Extracts were layered on serum in small $(2.7 \mathrm{~mm})$ tubes and kept at room temperature. Ring formation, between serum and extract, was checked at intervals up to I h.

Growth of cultures and DNA preparation. Each strain was grown in 21 of MRS at $37^{\circ} \mathrm{C}$ for $18 \mathrm{~h}$.

Labelled DNA was obtained from bacteria in the stationary phase grown in MRS medium with added $\left[{ }^{14} \mathrm{C}\right]$ uracil and $\left[{ }^{14} \mathrm{C}\right]$ adenine (each $50 \mu \mathrm{Ci} / \mathrm{l}$ ).

The bacteria were collected by centrifuging, washed twice in saline and suspended in $0.15 \mathrm{M}-\mathrm{NaCl}$ with $\mathrm{O} \cdot \mathrm{I} \mathrm{M}-\mathrm{EDTA}$ (disodium ethylene diamine tetra acetate) ( $\mathrm{pH} 8.0$ ) and then stored at $-25^{\circ} \mathrm{C}$.

Bacterial lysis was carried out by the addition of $40 \mathrm{mg}$ of lysozyme to suspensions, followed by incubation at $37{ }^{\circ} \mathrm{C}$ for $16 \mathrm{~h}$. Then $\mathrm{I} 5 \mathrm{mg}$ of pronase was added and incubation continued for a further $8 \mathrm{~h} ; 2.5 \mathrm{ml}$ of sodium lauryl sulphate was then added and the DNA extracted and purified by the method of Marmur (I96I).

All DNA preparations were stored at $4{ }^{\circ} \mathrm{C}$ in $0 . \mathrm{I} \times \mathrm{SSC}(0.015 \mathrm{M}-\mathrm{NaCl}$ and $0.0015 \mathrm{M}-$ trisodium citrate at $\mathrm{pH} 7 \cdot 0$ ) over chloroform.

DNA immobilization. Native DNA at a concentration of about $80 \mu \mathrm{g} / \mathrm{ml}$ in $0.1 \times$ SSC was alkali-denaturated $(\mathrm{O} \cdot \mathrm{I} \mathrm{M}-\mathrm{KOH}$ final concentration for I $5 \mathrm{~min})$ and neutralized with $2 \mathrm{~N}-\mathrm{HCl}$ at room temperature.

The denaturated DNA was then diluted I : 10 with ice-cold $6 \times \mathrm{SSC}$ and filtered through I $5 \mathrm{~cm}$ membrane filters (Sartorius SM 11306 ) that had been presoaked for $\mathrm{I} 2 \mathrm{~h}$ in $6 \times \mathrm{SSC}$. The filters were washed with $200 \mathrm{ml}$ of $6 \times \mathrm{SSC}$, dried overnight in air at room temperature and then cut with a paper punch into smaller disks of $10.5 \mathrm{~mm}$ diam. which were dried in a vacuum oven at $80^{\circ} \mathrm{C}$ for $2 \mathrm{~h}$ and stored at $4{ }^{\circ} \mathrm{C}$. The concentration of DNA on each stored filter ranged from 30 to $50 \mathrm{mg}$ as calculated from the extinction at $260 \mathrm{~nm}$ of the filtrate.

DNA molecular hybridization. An annealing temperature of $65^{\circ} \mathrm{C}$ was selected for DNA molecular hybridization because the melting temperatures $\left(T_{m}\right)$ in $\mathrm{I} \times \mathrm{SSC}$ of all our strains ranged from 84.30 to $90.45{ }^{\circ} \mathrm{C}$. Annealing temperatures of $25^{\circ} \mathrm{C}$ below the $T_{m}$ have been found to minimize adventitious pairing of bases (Marmur \& Doty, I96I). The single point competition version under the conditions recommended by Johnson \& Ordal (1968) was used. The filters, with DNA fixed to them, were preincubated for 4 to $6 \mathrm{~h}$ at $65^{\circ} \mathrm{C}$ in the mixture of Denhardt (I966) made up with $2 \times$ SSC. Each one was then transferred to a $4 \mathrm{ml}$ vial containing $0.25 \mathrm{ml}$ of Denhardt (I 966 ) mixture, $\mathrm{I} \cdot 0$ to $2 \cdot 0 \mu \mathrm{g}$ of heat-denaturated labelled DNA and $\mathrm{I} 50 \mu \mathrm{g}$ of heat-denaturated competitor DNA in $2 \times$ SSC. (DNA samples in $0 . \mathrm{I} \times$ SSC, previously sheared with a French pressure cell at about $10000 \mathrm{lb} / \mathrm{in}^{2}$ (McCarthy \& Bolton, 1963), were denaturated, prior to use, by heating in a boiling water bath for $10 \mathrm{~min}$.) The vials were gently shaken for $\mathrm{I} 2 \mathrm{~h}$ at $65{ }^{\circ} \mathrm{C}$. The filters were then washed with $2 \times \mathrm{SSC}$ at $65^{\circ} \mathrm{C}$, dried and counted in a Phillips model LSA 420 liquid scintillation counter using PPO plus POPOP scintillation liquid ( $0 \cdot 1 \mathrm{~g}$ POPOP plus $5 \mathrm{~g}$ PPO in I 1 toluene).

The extent of homology was calculated by the equation:

$$
\frac{\text { CPM homologous }- \text { CPM heterologous competitor system }}{\text { CPM homologous }- \text { CPM homologous competitor system }} \times 100 \text {. }
$$

Release of bound DNA from filters during incubation in Denhardt (I966) mixture was not taken into consideration because the temperature of incubation $\left(65^{\circ} \mathrm{C}\right)$ was in the range of validity of the filter method (De Ley \& Tijtgat, 1970) and because the amount of DNA fixed in the absence of competitor was 20 to $30 \%$ of the input. 
Determination of DNA base composition. Melting temperature values were obtained with native DNA dissolved in $\mathrm{I} \times \mathrm{SSC}$; cuvettes were heated gradually with circulating water and variations in extinction at $260 \mathrm{~nm}$ recorded with Beckman DK $2 \mathrm{~A}$ spectrophotometer. The base composition ( $\% \mathrm{GC}$ ) was calculated from $T_{m}$ by the equation of De Ley (1970):

$$
\% \mathrm{GC}=\left(T_{m}-69 \cdot 37\right) / 0 \cdot 4 \mathrm{I} .
$$

\section{RESULTS}

\section{Relations of Lactobacillus lactis and L. bulgaricus}

The fermentation patterns, serological groups, moles \% GC and DNA homologies are given in Table 2. Seven of the eight strains of $L$. lactis and five of the six strains of $L$. bulgaricus showed 72 to $100 \%$ homology with the reference strains of both L. lactis (ATCC I I06I) and L. bulgaricus (ATCC I I842). Of these seven strains of $L$. lactis three (ATCC I I06I, NIRDL20 and NIRDAHI6) did not compete in the homologous system of either L. jugurti (ATCC 52I) or L. helveticus (NIRDHI); L. lactis strains (NIRDL27 and NIRDLI) gave levels of homology of 28 and $43 \%$ respectively with L. jugurti (ATCC 52I) but not with L. helveticus (NIRDHI); $L$. lactis strains (NIRDL3 and NIRDAH40) showed some homology to both $L$. jugurti (ATCC 52I) and L. helveticus (NIRDHI).

The strain NIRDLI2, which could be considered as Lactobacillus lactis by its fermentation pattern, showed an appreciable level of homology $(46 \%)$ only with the reference strain ATCC I 1842 of L. bulgaricus. The results with this strain in the DNA hybridization support the differences found in other characteristics: it belongs to serological group A and has a low $\%$ GC $(36 \%)$.

The strains of Lactobacillus bulgaricus, except ATCC I 2278, were highly homologous (80 to IOI \%) to L. lactis (ATCC I I06I) and to L. bulgaricus (ATCC I I842), but did not show similarity to L. jugurti (ATCC 52I) except for ATCC I 2278 and to a lesser extent strain BI7. Their relationship to $L$. helveticus was, however, not assessed.

Lactobacillus bulgaricus ATCC 12278 displays the fermentation pattern of the species $L$. bulgaricus but belongs to serological group A and its DNA base composition of $38.2 \%$ GC is not in conformity with typical strains of this species (group $\mathrm{E}$ and $\%$ GC 50 to $5 \mathrm{I}$ ). Its very high homology level to L. helveticus (NIRDHI) and L. jugurti (ATCC 52I) supports the opinion already expressed by Miller et al. (I97I) that the strain should be reclassified.

\section{Relations of Lactobacillus helveticus and L. jugurti}

The results with these strains (Table 3) show that DNA preparations from all the strains behaved similarly although classified differently. The eight strains of $L$. helveticus and ten strains of $L$. jugurti all had similar DNA base compositions ( 36 to $38 \% \mathrm{GC}$ ) and belonged to serological group A (five strains of $L$. jugurti were not tested). The species differed in fermentation of maltose and fructose and to some extent trehalose (Table 3). The DNA of all 18 strains competed to the same high levels (85 to 102\%) with DNA of the reference strains, L. helveticus (NIRD HI) and L. jugurti (ATCC 52I). Low levels of homology (O to 29\%) were obtained between the DNA of L. lactis (ATCCIIO6I) and L. bulgaricus (ATCC I I842).

\section{Relations of unnamed isolated thermophilic lactobacilli}

The results with 13 strains of thermophilic lactobacilli, isolated from natural whey cheese cultures, are summarized in Table 4. In general the strains gave good agreement with each other in fermentation pattern, serological group and DNA base composition. 
Thermophilic lactobacilli

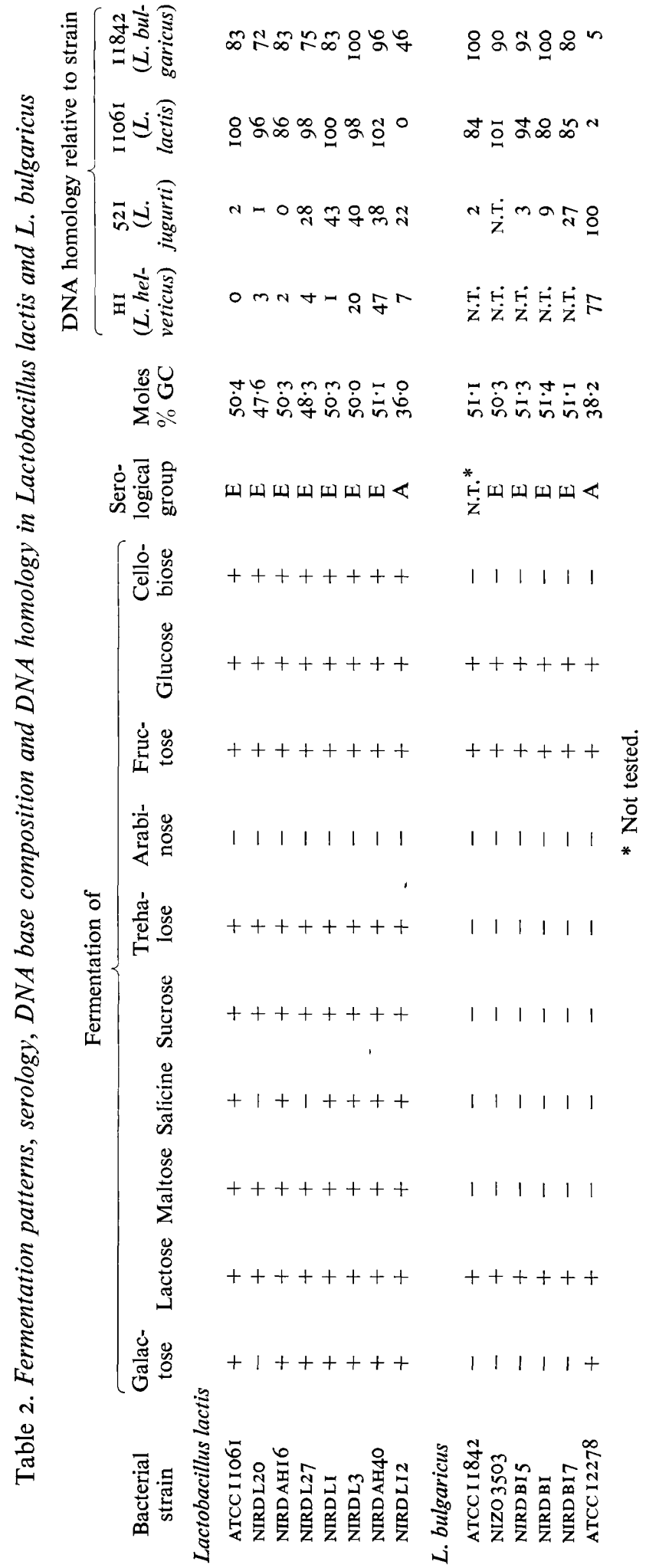




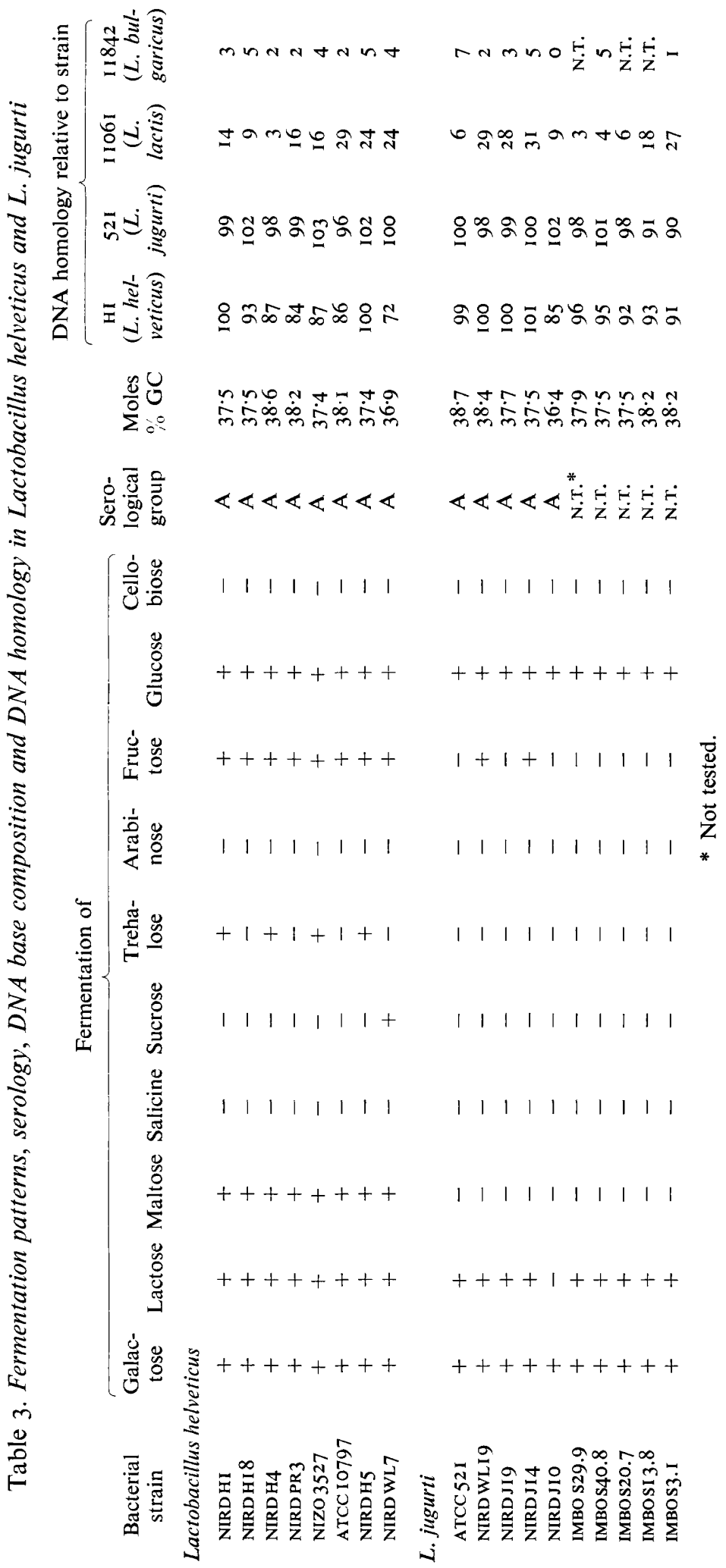




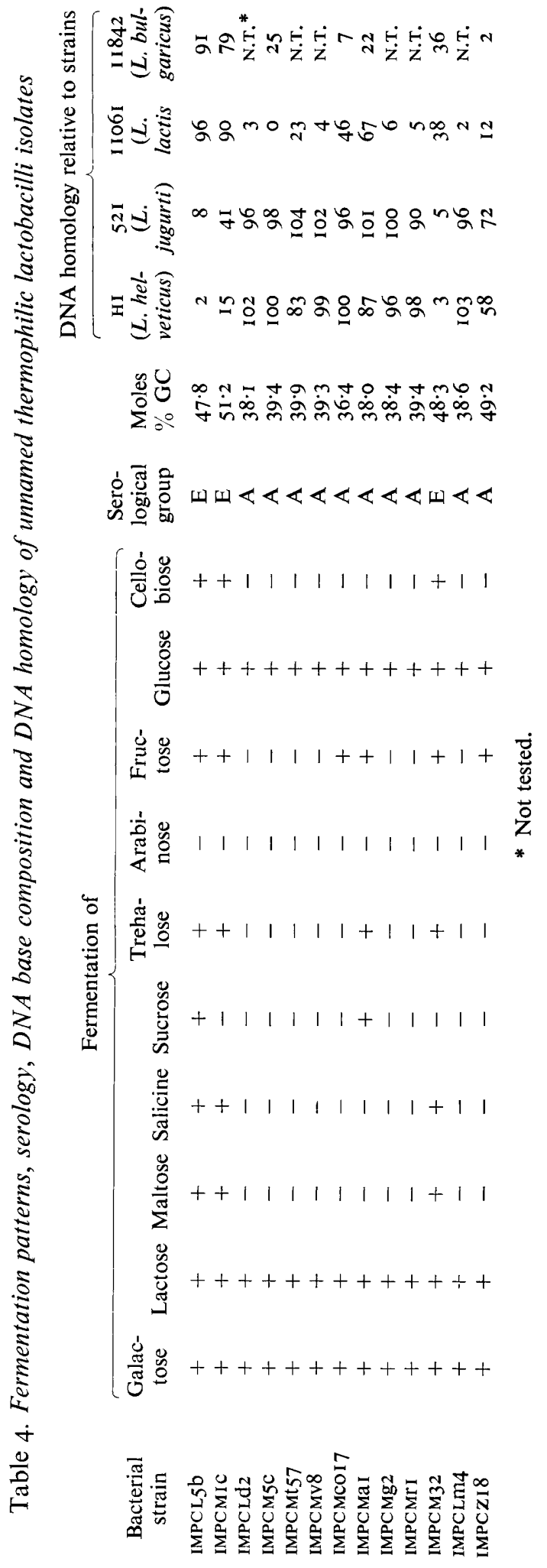


Eight strains (Ld2, M5C, Mt57, Mv8, Mco I7, Mg2, MrI and Lm4) gave high levels of DNA homology with Lactobacillus helveticus (NIRD HI) and L. jugurti (ATCC 52I) which might be expected from their fermentation patterns, serology (A) and \% GC (36 to 39). Strains L5b and MIC were similar to L. lactis group in fermentation and to both L. lactis and L. bulgaricus in serology (E) and \% GC (47 to 5I). These similarities were supported by homology results.

Strain M32 competed to a limited extent with Lactobacillus lactis (ATCC I I06I) and $L$. bulgaricus (ATCC I 1842) although it belonged to serological group E and had a \% GC of 48 .

Strain ZI8 did not correspond completely to any named species as it fermented fructose like Lactobacillus bulgaricus, but also fermented galactose like $L$. jugurti; it belonged to serological group A like L. jugurti and L. helveticus but had a \% GC of 49·2.

\section{DISCUSSION}

Although limited in the number of strains, the results given indicate a close genetic similarity between Lactobacillus lactis and L. bulgaricus.

The results support the findings of Simonds et al. (197I), who first reported the similarity of base sequences in the DNA of $L$. bulgaricus ATCC II842 and L. lactis ATCCI23I5.

Miller et al. (I97I) did not find any similarities between Lactobacillus bulgaricus ATCC I 2278 and $L$. lactis 39 -A and concluded that $L$. bulgaricus ATCC I 2278 should be classified as $L$. helveticus. We found (Table 2) that L. bulgaricus ATCC I 2278 gave $77 \%$ homology with the reference strain L. helveticus (NIRDHI), but $100 \%$ homology with $L$. jugurti (ATCC 52I). In addition, the strain did not ferment maltose and could be classified as L. jugurti.

The close genetic relation of Lactobacillus helveticus and L. jugurti, as confirmed by our results, was suggested, on phenotypic grounds, by Rogosa \& Sharpe (1959). Miller et al. (197I) found that L. helveticus (strain osu) and L. jugurti (ATCC 52I) gave only 55\% homology and suggested that these two strains were distinct. However, the strain osu is probably incorrectly classified.

Strain ZI 8 formed DL-lactic acid like Lactobacillus helveticus and L.jugurti, was strongly proteolytic unlike the majority of thermophilic lactobacilli (Bottazzi, I962 $b$ ) and presented the same amino acid composition as L. lactis (Bottazzi, I962a). Its DNA did not give conclusive homology values with the reference strains although it seemed to be more related genetically to $L$. jugurti and L. helveticus than to L. lactis and L. bulgaricus. Strain zI 8 might belong to a so far unrecognized group of lactobacilli.

Our results are thus in line with the current ideas on the taxonomy of the four named species studied. However, a more comprehensive taxonomic rearrangement of lactobacilli (Gasser \& Sebald, I966) requires more DNA homology studies on a much larger number of strains.

This investigation was supported in part by a grant of Consiglio Nazionale della Ricerche (CNR). We thank Professor V. Scardovi, University of Bologna, Italy, for his helpful criticism of the manuscript and Dr P. G. Sarra, Istituto di Microbiologia lattierocasearia, Università Cattolica del Sacro Cuore, Piacenza, Italy, for his technical assistance. 


\section{REFERENCES}

BotTazzI, V. (1962a). Effect of purines upon the growth in milk of Lactobacillus lactis. XVIth International Dairy Congress, Section III, subject 2, pp. 33I-334.

BottazzI, V. $(1962 b)$. Proteolytic action of some strain of thermophilic lactobacilli. XVIth International Dairy Congress, Section IV, subject I, pp. 522-528.

Breed, R. S., Murray, E. G. D. \& Smith, N. R. (1957). Bergey's Manual of Determinative Bacteriology, 7 th edn. Baltimore: Williams \& Wilkins.

DE LEY, J. (1970). Reexamination of the association between melting point, buoyant density and chemical base composition of deoxyribonucleic acid. Journal of Bacteriology ror, 738-754.

DE Ley J. \& TIJTGAT, R. (1970). Evaluation of membrane filter methods for DNA-DNA hybridization. Antonie van Leeuwenhoek 36, 46I-474.

De Man, J. C., Rogosa, M. \& Sharpe, M. E. (I960). A medium for the cultivation of lactobacilli. Journal of Applied Bacteriology 23, 130-I35.

DenhardT, D. T. (1966). A membrane filter technique for the detection of complementary DNA. Biochemical and Biophysical Research Communication 23, 641-646.

Gasser, F. \& Sebald, M. (1966). Composition en bases nucleiques des bactéries du genre Lactobacillus. Annales Institute Pasteur de Lille Iro, 261-275.

Hansen, P. A. (1968). Type Strains of Lactobacillus species. A Report by the Taxonomic Subcommittee on Lactobacilli and Closely Related Organisms. Rockville, Maryland: American Type Culture Collection.

Johnson, J. L. \& Ordal, E. J. (I968). Deoxyribonucleic acid homology in bacterial taxonomy: effect of incubation temperature on reaction specificity. Journal of Bacteriology 95, 893-900.

MCCARthy, B. J. \& Bolton, E. T. (I963). An approach to the measurement of genetic relatedness among organisms. Proceedings of the National Academy of Sciences of the United States of America 50, 156-164.

MARMUR, J. (1961). A procedure for the isolation of deoxyribonucleic acid from micro-organisms. Journal of Molecular Biology 3, 208-2 18.

MARMur, J. \& Doty, P. (I96I). Thermal denaturation of deoxyribonucleic acid. Journal of Molecular Biology 3, 585-594.

Miller, A. III, Sandine, W. E. \& Elliker, P. R. (I97I). Deoxyribonucleic acid homology in the genus Lactobacillus. Canadian Journal of Microbiology 17, 625-630.

Orla-Jensen, S. (1919). The Lactic Acid Bacteria. Edited by Andr. Fred. Copenhagen: Host. \& Son.

Rogosa, M. \& Sharpe, M. E. (I959). An approach to the classification of lactobacilli. Journal of Applied Bacteriology 22, 329-340.

Scardovi, V., Trovatelli, L. D., Zani, G., Crociani, F. \& Matteuzzi, D. (I97i). Deoxyribonucleic acid homology relationships among species of the genus Bifidobacterium. International Journal of Systematic Bacteriology 21, 276-294.

Sharpe, M. E. (I955). A serological classification of lactobacilli. Journal of General Microbiology 12, 107-1 22.

Sharpe, M. E. (196I). Taxonomie des Lactobacilli. Annales Institute Pasteur de Lille 12, I28-163.

Simonds, J., Hansen, P. A. \& Lakshmanan, S. (1971). Deoxyribonucleic acid hybridization among strains of lactobacilli. Journal of Bacteriology ro7, 382-384. 